\title{
GENETIC IDENTIFIABILITY OF SELECTED POPULATIONS OF INDIAN MACKEREL, RASTRELLIGER KANAGURTA (ACTINOPTERYGII: PERCIFORMES: SCOMBRIDAE)— CELFISH PROJECT-PART 1
}

\author{
Maciej KIELPINSKI ${ }^{1}$, Jolanta KEMPTER ${ }^{1 *}$, Remigiusz PANICZ ${ }^{1}$, and Slawomir KESZKA ${ }^{2}$ \\ ${ }^{1}$ Division of Aquaculture, West Pomeranian University of Technology, Szczecin, Poland \\ ${ }^{2}$ Division of Hydrobiology, Ichthyology, and Biotechnology of Breeding, \\ West Pomeranian University of Technology, Szczecin, Poland
}

\begin{abstract}
Kielpinski M., Kempter J., Panicz R., Keszka S. 2014. Genetic identifiability of selected populations of Indian mackerel, Rastrelliger kanagurta (Actinopterygii: Perciformes: Scombridae)-CELFISH Project—Part 1. Acta Ichthyol. Piscat. 44 (2): 145-152.
\end{abstract}

\begin{abstract}
Background. Genetic traceability of seafood as well as population identification using molecular methods provide useful information about the fish origin and are important for protection of overfished populations, as well as for monitoring illegal, unreported, and unregulated (IUU) fisheries. The presently reported study focused on Indian mackerel, Rastrelliger kanagurta (Cuvier, 1816) - a pelagic species with a wide range of distributionespecially important for many tropical countries, such as India, Philippines, and Thailand. This paper is the first part of a larger project: "Development of a genetic-based system for identification of food products from fisheries and aquaculture introduced to the European Union customs area".

Materials and methods. Samples consisting of fin fragments of Indian mackerel were obtained from local markets in Thailand (MTH), Vietnam (SVN), Cambodia (SKH), and Madagascar (SMG) within 2012-2013. Two genes were analysed: nuclear rhodopsin gene (RH1) and mitochondrial D-loop (D-loop) region through RFLP analysis simulation and sequencing. Additionally, the samples from Cambodia and Madagascar were analysed with eight microsatellite loci (SSR). The data processing was aided by GenAlEx 6.5 and GeneClass2 software. Results. A comparison of the RH1 gene section revealed a total homology among the studied samples. A comparative analysis of D-loop sequences in the studied groups revealed intrapopulational diversity for MTH-, SKH, SMG-, and SVN samples, at the level of $1,1,0.5$, and 0.6 percentage points, respectively. Furthermore, the D-loop sequences identified a characteristic restriction site for SMG population. Based on the allele frequencies, we randomly assigned selected individuals to their original populations. GeneClass2 software correctly assigned only 16 out of 21 individuals to either the Cambodian or the Madagascar population, which jointly constituted $76 \%$ of all samples. We demonstrated, using AMOVA and GenAlEx 6.5, that the highest level of variability occurred among individuals within the respective populations, while the lowest interpopulation diversity was between the SMG and SKH populations.

Conclusion. Our results may help the relevant authorities in the countries of the European Union to identify Indian mackerel and especially its products and trace them to the respective locality. Our findings may also be used for species-specific conservation measures hopefully undertaken by fisheries authorities of the countries where we took our samples. Results on other fish species, prepared in the frames of the same project, will be presented in other papers that will follow soon.
\end{abstract}

Keywords: microsatellite, genetic traceability, seafood authentication, seafood counterfeiting

\section{INTRODUCTION}

Genetic identification of food ingredients is an important method that enables the traceability and confirmation of authenticity of fish products. With regard to common cases where valuable fish species are replaced by lowvalue equivalents it is necessary to provide reliable meth- ods which will precisely identify fish species that are valuable for economy. Such methods help to eliminate counterfeit products from the market but also provide tools that might be used by governmental units which control food safety, including custom services. Population identification by molecular methods also provides infor-

\footnotetext{
* Correspondence: Dr hab. Jolanta Kempter, Zakład Akwakultury, Wydział Nauk o Żywności i Rybactwa. Zachodniopomorski Uniwersytet Technologiczny w Szczecinie, ul. Kazimierza Krolewicza 4, 71-550 Szczecin, Poland, phone: +48 91449 6663, e-mail: (JK) jolanta.kempter@zut.edu.pl, (MK) mkielpinski@zut.edu.pl, (RP) rpanicz@zut.edu.pl, (SK)skeszka@zut.edu.pl.
} 
mation about the catch region (Fisher 2013), which is highly useful in protection strategies of overfished populations, or catches from illegal, unreported, and unregulated (IUU) fisheries.

The results presented in this paper are part of a larger research project entitled "Development of a genetic-based system for identification of food products form fisheries and aquaculture introduced to the European Union customs area" and carried out within 2011-2013 (see details in Acknowledgements).

The Indian mackerel, Rastrelliger kanagurta (Cuvier, 1816), is a pelagic species with a wide range of distribution, inhabiting mainly the Indian Ocean and western part of the Pacific. Its southern and northern limits are higher latitudes (e.g., southern Madagascar and southern Japan, respectively). It has special significance in the economy of the countries in the tropical region, where the species is considered an important source of inexpensive protein and is also commonly used as bait (Froese and Pauly 2014). Due to the special importance of the species for the countries surrounding the Pacific Ocean, numerous investigations have been conducted to differentiate its populations and provide their genetic identification. The studies of Jayasankar et al. (2004) revealed genetic variability of three populations inhabiting the waters off the eastern and western coast of India. A similar study by Ghazali et al. (2012) analysed haplotypes of all five populations (Kota Kinabalu, Kudat, Sandakan, Tawau, and Semporna) and concluded that they were genetically homogeneous. The problem of genetic identification and variability of the Indian mackerel populations was also discussed at the 8th Malaysia Genetics Congress that was held in Pahang (2009). No significant differences were found among populations from west coast of Peninsular Malaysia on the basis of the morphometric and RAPD analysis (Darlina et al. 2011).

In 2011, the total catch of the Indian mackerel amounted to $117000 \mathrm{t}$ in the Pacific, and 116000 and $60000 \mathrm{t}$ in the western and southern parts of the Indian Ocean, respectively (Anonymous 2013). Major exploiters of the species include India (ca. $100000 \mathrm{t}$ ), Philippines, and Thailand. In India, the Indian mackerel comes tenth on the list of ten fish species which are the most important for economy. The wide range of the Indian mackerel, the high extent of the fisheries pressure, as well as its importance for fisheries economies of all countries involved call for prompt conservation measures imposed for individual populations of the species. One possible approach would be by careful population management especially for declining populations or those with insufficiently diversified age structure. In the case of marine fish, their natural tendency for migration and possible overlapping of their migration routes render the implementation of such protective measures difficult. So far, it has not been possible to identify with the aid of RAPD or mtDNA (cyt-b) analyses the markers specific for particular populations. The analysis of microsatellite markers allows for identification of unique allele variants occurring only in individuals representing particular populations.

\section{MATERIALS AND METHODS}

The CELFISH project covered two years of sampling at numerous localities scattered all over the world. The travel schedules, the methodology of sampling, as well as subsequent laboratory analyses were very carefully designed to assure the reliable effect that could be achieved in the prescribed time frames. The exact origin of the fish was important, therefore to assure that two-person teams of the present authors travelled to carefully planned destinations, where they picked fish markets and the merchants known to trade only local fish. The fish were identified on the spot by the authors. In the frames of presently reports study we travelled to Thailand (MTH), Vietnam (SVN), Cambodia (SKH), and Madagascar (SMG) within 2012-2013. The study material was collected from fins of the Indian mackerel, Rastrelliger kanagurta. The fin fragments were excised from fish, which were randomly selected from the whole catch. Therefore samples represent $R$. kanagurta populations from all above-mentioned regions. We would like to emphasize that every possible effort was made to collect Indian mackerel samples from the geographical areas where naturally occur. Specific data on respective locations and numbers of individuals are given in Table 1. Collected fin fragments were dried and then preserved in $5-\mathrm{mL}$ test tubes containing a silicone medium. DNA isolation from the fin fragments was conducted using a DNeasy Blood and Tissue Kit (Qiagen) according to manufacturer recommendations. Qualitative and quantitative evaluation of the isolates was based on the separation in $1.5 \%$ agarose gel and spectrophotometric measurements made with NanoDrop 2000 (Thermo Scientific). Two PCR reactions were conducted for all samples. The first focused on the amplification of a fragment of the nuclear rhodopsin gene (RH1), and the second on the displacement-loop (D-loop) region of mitochondrial DNA. Reactions were based on primers: Rod-F2W + Rod-R4n (Sevilla et al. 2007) and L16473 + H355 (Imsiridou et al. 1998) respectively, according to methodological guidelines provided by the authors. Additionally, for samples obtained from Cambodia (SKH) and Madagascar (SMG), the analysis of eight microsatellite regions (SSR) was conducted: Orla3-65,

Table 1

Summary of sampled populations of Indian mackerel, Rastrelliger kanagurta, localities, GPS coordinates and number of specimens

\begin{tabular}{lllr}
\hline Country & Location & Coordinates & $N$ \\
\hline \multirow{3}{*}{ Thailand } & Bangkok & $13^{\circ} 30^{\prime} \mathrm{N}, 100^{\circ} 40^{\prime} \mathrm{E}$ & 4 \\
& Phuket & $7^{\circ} 48^{\prime} 17^{\prime \prime} \mathrm{N}, 98^{\circ} 17^{\prime} 51^{\prime \prime} \mathrm{E}$ & 3 \\
& Koh Samui & $9^{\circ} 30^{\prime} \mathrm{N}, 100^{\circ} 00^{\prime} \mathrm{E}$ & 10 \\
Vietnam & Quy Nhơ & $13^{\circ} 46^{\prime} \mathrm{N}, 109^{\circ} 14^{\prime} \mathrm{E}$ & 4 \\
Cambodia & Phnom Penh & $11^{\circ} 31^{\prime} \mathrm{N}, 104^{\circ} 56^{\prime} \mathrm{E}$ & 12 \\
& Toamasina & $18^{\circ} 09^{\prime} \mathrm{S}, 49^{\circ} 25^{\prime} \mathrm{E}$ & 4 \\
Madagascar & $1^{\circ} 22^{\prime} \mathrm{S}, 49^{\circ} 25^{\prime} \mathrm{E}$ & 5 \\
& Fenoarivo & & \\
\hline
\end{tabular}

$N=$ number of specimens. 
Orla3-185, Orla7-124, Orla16-185, Orla18-49, Orla9-204, Orla16-32, and Orla21-231 (Gotoh et al. 2013). Both localizations were selected according to the highest sample number. Moreover, the populations represent two distinct geographical regions, therefore we decided to exclude from SSR analysis samples from Vietnam (SVN) and Thailand (MTH). The amplification of regions was conducted according to the methodology proposed by Gotoh et al. (2013). The only modification made in the original protocol was that the standard PCR profile had during first 7 cycles of primer attachment higher $\left(62^{\circ} \mathrm{C}\right)$ temperature to increase specificity. PCR reactions were performed as follows: $94^{\circ} \mathrm{C}$ for $5 \mathrm{~min}$, followed by 30 denaturation cycles $\left(94^{\circ} \mathrm{C}, 45 \mathrm{~s}\right)$, primer attachment $\left(62^{\circ} \mathrm{C}, 30 \mathrm{~s} \times 7\right.$ and $\left.59^{\circ} \mathrm{C}, 30 \mathrm{~s} \times 27\right)$, primer elongation $\left(72^{\circ} \mathrm{C}, 20 \mathrm{~s}\right)$, and final extension $\left(72^{\circ} \mathrm{C}\right.$ for $\left.7 \mathrm{~min}\right)$. The reaction mixture was prepared on the basis of REDTaq ReadyMix PCR Reaction Mix (Sigma-Aldrich): REDTaq ReadyMix $12.5 \mu \mathrm{L}$, primer F $0.5 \mu \mathrm{L}\left(10 \mathrm{pmol} \cdot \mu \mathrm{L}^{-1}\right)$, primer R $0.5 \mu \mathrm{L}\left(10 \mathrm{pmol} \cdot \mu \mathrm{L}^{-1}\right)$, $\mathrm{H}_{2} \mathrm{O}$ DEPC $10.5 \mu \mathrm{L}$, DNA $1 \mu \mathrm{L}$. All PCR reactions were conducted in a thermal cycler (GeneAmp ${ }^{\circledR}$ PCR System 9700, Applied Biosystems), and the result of amplification was evaluated by separation of the analysed amplicons in $2 \%$ agarose gel. Sequencing of the RH1 and D-loop PCR products were conducted by the service provider, Genomed (Warsaw, Poland). The alignments of obtained
RH1 and D-loop sequences were conducted using BioEdit and BLAST software (Altschul et al. 1990, Hall 1999). Additionally, D-loop sequences were analysed and characterised by following genetic indices as: polymorphic sites ( $)$, parsimony-informative sites (MP), number of haplotypes $(h)$ and nucleotide diversity $(\pi)$ in MEGA5 software (Tamura et al. 2011). Nucleotide sequences of D-loop were also analysed using NEBcutter web based program in order to identify point mutations that might be useful to design PCR-RFLP method for identification of Indian mackerel populations (Vincze et al. 2003). Separation of SSR fragments was conducted in a sequencer (SEQ 8000, Beckman Coulter). The analysis of obtained data was conducted with the aid of the software: GenAlEx 6.5 and GeneClass2 (Piry et al. 2004, Peakall and Smouse 2012).

\section{RESULTS}

A comparison of the RH1 gene revealed total homology among the studied samples of Indian mackerel, Rastrelliger kanagurta. A search for records conducted with the BLAST software in the NCBI (National Center for Biotechnology Information) database did not reveal any RH1 gene sequence for the Indian mackerel. Therefore, the RH1 sequences, $460 \mathrm{bp}$ in length, obtained in the present study were the first record for this species (Fig. 1). A comparative analysis of D-loop sequences in

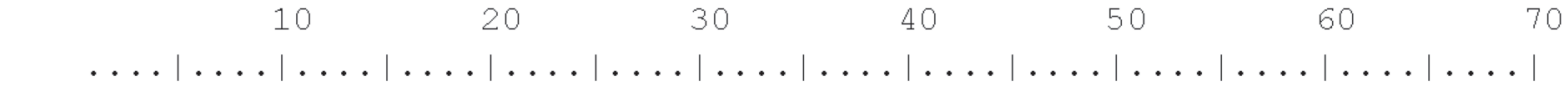 \\ 1 TCACGCCATCATGGGCTTGGCCTTGACCTGGGTAATGGCCTTTTCTTGTTCCGTGCCCCCTCTTGTCGGC

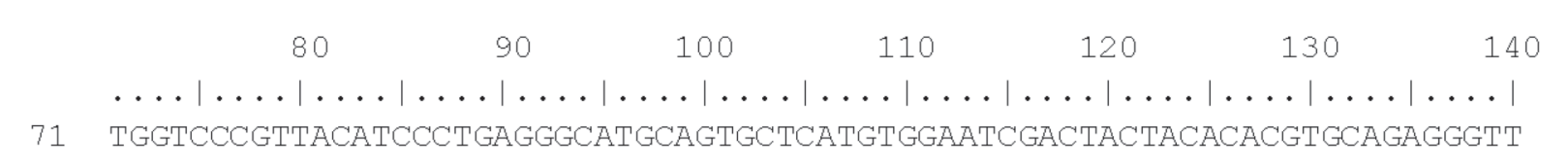
$\begin{array}{rrrrrrr}150 & 160 & 170 & 180 & 190 & 200 & 210\end{array}$

150
$\ldots \ldots|\ldots| \ldots|\ldots| \ldots|\ldots| \ldots|\ldots| \ldots|\ldots| \ldots|\ldots| \ldots|\ldots| \ldots|\ldots| \ldots|\ldots| \ldots|\ldots|$
141 TCAACAATGATACTTTCGTCATCTACATGTTCACATGCCACTTCATGATCCCACTGGTCGTTATCTTCTT

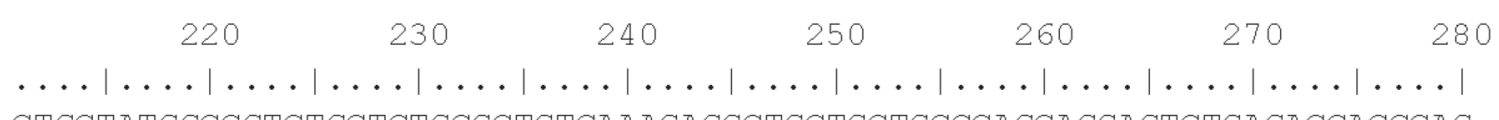

211 CTGCTATGGCCGTCTGCTCTGCGCTGTCAAAGAGGCTGCTGCTGCCCAGCAGGAGTCTGAGACCACCCAG

290
$\ldots \ldots|\ldots| \ldots|\ldots| \ldots|\ldots| \ldots|\ldots| \ldots|\ldots| \ldots|\ldots| \ldots|\ldots| \ldots|\ldots| \ldots|\ldots| \ldots|\ldots|$

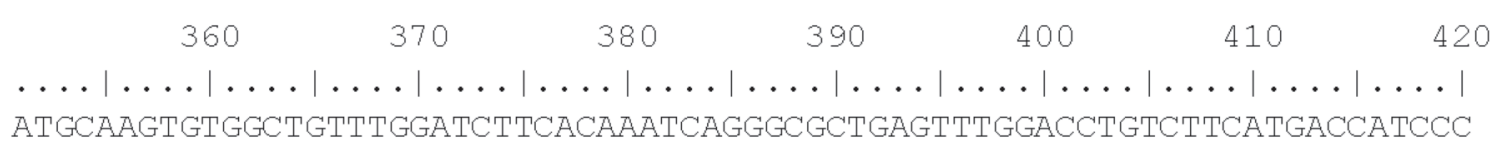

$$
\begin{gathered}
430 \\
\ldots 21 \text { GGCATTCTTTGCCAAGAGCTCTTCCATCTACAACCCATTG }
\end{gathered}
$$

Fig. 1. The rhodopsin (RH1) gene sequence of Indian mackerel, Rastrelliger kanagurta 
the studied groups revealed intrapopulational diversity for MTH, SKH, SMG, and SVN samples, at the level of 1, 1, 0.5 , and 0.6 percentage points, respectively. Interpopulational comparisons ranged from 0.9 to 1.6 percentage points and were presented in Table 2. Data on genetic variability of the respective populations are given in Table 3. Genetic distances obtained by applying the Kimura's two-parameter model (K2P) are given in Table 4 and illustrated by Neighbour-joining D-loop-based dendrogram (Fig. 2). Two unique transition mutations, at positions $364(\mathrm{C}->\mathrm{T})$ and $386(\mathrm{~A}->\mathrm{G})$, for individuals from Madagascar were observed. A comparison of the D-loop sequence characteristic for SMG population with the remaining groups using NEBcutter software singled out a restriction enzyme Cac8I (BstC8I), which recognized and potentially digested the sequence of that region depending on the presence of the GCNNGC motif. In individuals from the Madagascar population, contrary to those from the other populations, the characteristic motif was present and thus the described mutation was a potential marker identifying that population.

Population assignment of individuals of Rastrelliger kanagurta to their population was conducted on the microsatellite data on randomly chosen sequences. GeneClass 2 software correctly assigned only 16 out of 21 individuals to either the Cambodian or the Madagascar population, which jointly constituted $76 \%$ of all samples. On the basis of the molecular variance analysis (AMOVA) conducted using GenAlEx 6.5 software it was shown that the highest genetic variance occurred among individuals within populations, while the lowest level was variation between the SMG and SKH populations (Fig. 3). Furthermore, the number of polymorphic loci for each of the examined populations equalled $100 \%$, indicating a high allelic richness, characteristic for individuals living in large shoals. Principal component analysis conducted for genetic distances conducted with the aid of GenAlEx 6.5 software confirmed the results obtained with GeneClass2 software. On the basis of available data it was not possible to correctly assign particular individuals to their native populations as the percentage of common SSR variants was too high (Fig. 4).

\section{DISCUSSION}

Indian mackerel, Rastrelliger kanagurta, is a highly commercial species, caught with a number of different gears including purse-seines, fish corrals, gill-nets, cast and drift nets, and also by dynamiting. It is marketed fresh, frozen, canned, dried salted, and smoked (Collette 2001). No information is available on its population structure or general abundance. The species is targeted in commercial and artisanal fisheries throughout its range, but landings are primarily reported in combination with mixed Rastrelliger spp. Landings reported worldwide for Rastrelliger species have steadily increased since 1950 to exceed $800000 \mathrm{t}$, but no effort information is available. Given that the effort is assumed to be increasing and that there is some evidence of localized declines, it is not known how the population of this species has been affected by current and historical fishing pressure (Rohit and Gupta 2004). The Indian mackerel is listed as Data Deficient (Collette et al. 2011). Given the absence of an international management body, further monitoring of this species is needed on the national level, in addition to species-specific data on landings, effort and population status.

Interpopulational diversity of the Indian mackerel, Rastrelliger kanagurta, has been repeatedly analysed using both RFLP and mtDNA analyses. However, group mobility, natural migration, and shoaling, have rendered the task difficult. There are many reports on life history and other information on this species compared to other Rastrelliger species (Noble and Geetha 1992). The species occurs in coastal bays, harbours and deep lagoons, usually in some turbid, plankton-rich waters. It is a common, coastal pelagic species, often found in large schools. Off India, batch spawning extends from March through September. The size at first maturity is approximately 17-20 cm (Tampubolon and Merta 1987, Sivadas et al. 2006), and its longevity is estimated to be approximately four years (Mehanna 2001).

The Indian mackerel is intensely exploited by countries surrounding the Andaman Sea, Bay of Bengal, Arabian Sea, Gulf of Thailand, and the southern China Sea. In India, from 1993 to 1999, annual average catch was around $200000 \mathrm{t}$ but later declined to $90000 \mathrm{t}$ (Anonymous 2013). In Eastern India, this species is considered to be exploited at higher-than-optimum levels, indicating the fishing pressure exceeding the sustainable

Table 2

D-loop sequence variation between the studied populations of Indian mackerel, Rastrelliger kanagurta,

based on Kimura's two-parameter model (K2P)

\begin{tabular}{lccc}
\hline MTH & SKH & SMG & SVN (pooled) \\
\hline SKH & 0.009 & & \\
SMG & 0.016 & 0.015 & \\
SVN (pooled) & 0.010 & 0.010 & 0.012 \\
\hline
\end{tabular}

$\mathrm{MTH}=$ Thailand, $\mathrm{SKH}=$ Cambodia, $\mathrm{SMG}=$ Madagascar $\mathrm{SVN}=$ Vietnam.

Table 3

Genetic variability parameters of sequence groups in samples of the studied populations

of Indian mackerel, Rastrelliger kanagurta from Thailand, Cambodia, Madagascar, and Vietnam

\begin{tabular}{lrrcrc}
\hline Group (sample) & $n$ & $\eta$ & MP & h & $\pi$ \\
\hline MTH & 17 & 16 & 8 & 12 & 0.00946 \\
SKH & 5 & 9 & 3 & 5 & 0.00955 \\
SMG & 9 & 10 & 1 & 8 & 0.00543 \\
SVN (pooled) & 4 & 5 & 0 & 2 & 0.00568 \\
\hline
\end{tabular}

$n=$ number of sequences, $\eta=$ number of polymorphic sites, $\mathrm{MP}=$ parsimony-informative sites, $h=$ number of haplotypes, $\pi=$ nucleotide diversity, MTH $=$ Thailand, SKH $=$ Cambodia, $\mathrm{SMG}=$ Madagascar, $\mathrm{SVN}=$ Vietnam. 


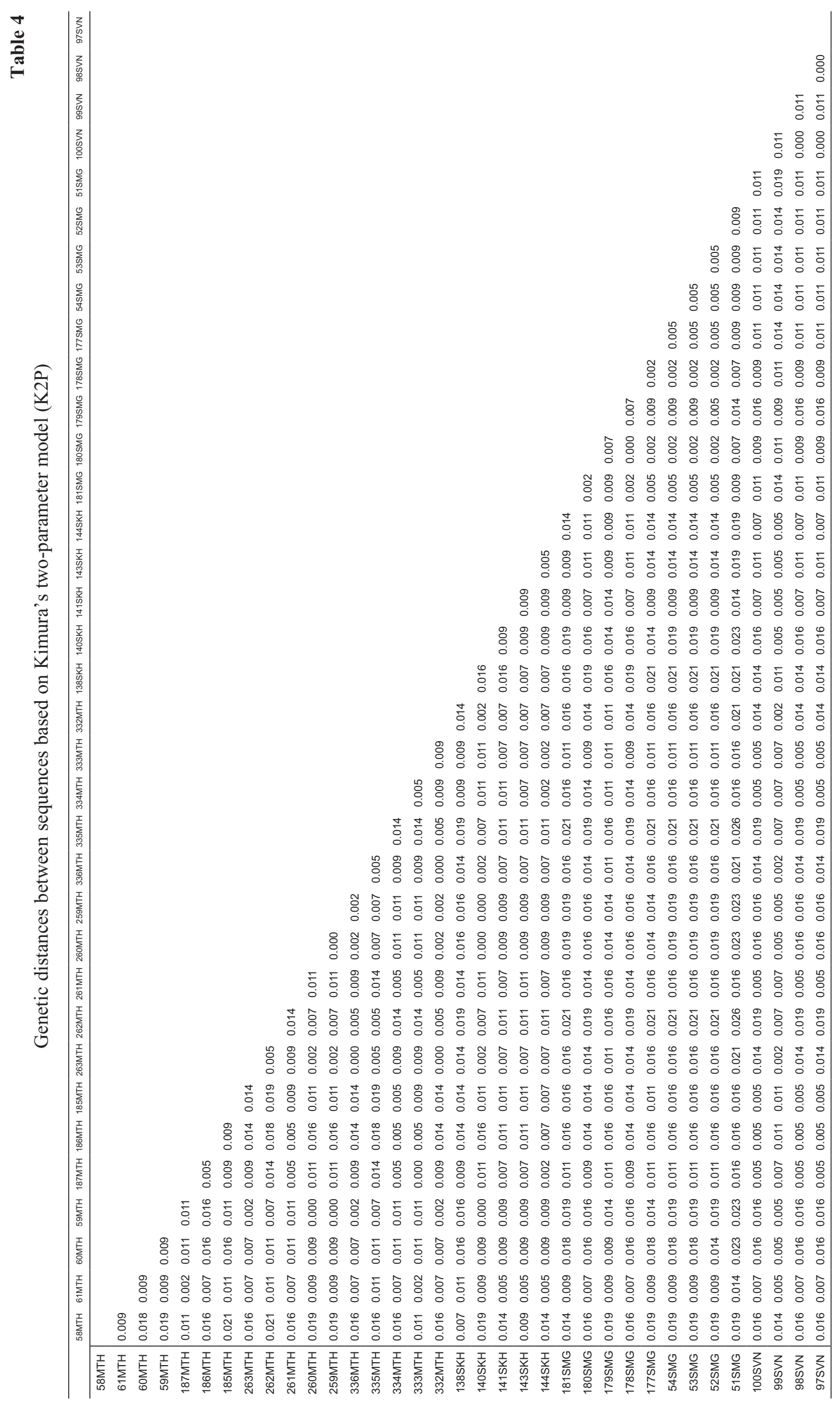


levels (Rohit and Gupta 2004). Other studies (Abdussamad et al. 2010) report that because the species matures at an early age and spawns round the year, the present fishing pattern appears to have no adverse impact on recruitment; currently the resource is exploited near the optimum level and there appears to be no immediate threat for the stock.

Due to the absence of regulations and catch limits in the countries where the catch of the Indian mackerel is the highest according to the FAO (India, Philippines, Indonesia, and Pakistan), the population stability should be analysed and its intrapopulation genetic diversity should be evaluated. A cladistic analysis resulted in differentiating populations from Vietnam and Madagascar (separate clades, see Fig. 2), while Indian mackerel populations from Thailand and Cambodia were genetically mixed. Perhaps the shoals mix in the Gulf of Thailand, since the time and place of their spawning coincide. According to Hansen et al. (2001), thanks to microsatellite markers it is possible to confirm genetic differences within a population, therefore we assume that microsatellite analysis proposed in this paper was a useful and reliable method. This means that microsatellite sequences are variable regions, within which markers characterizing

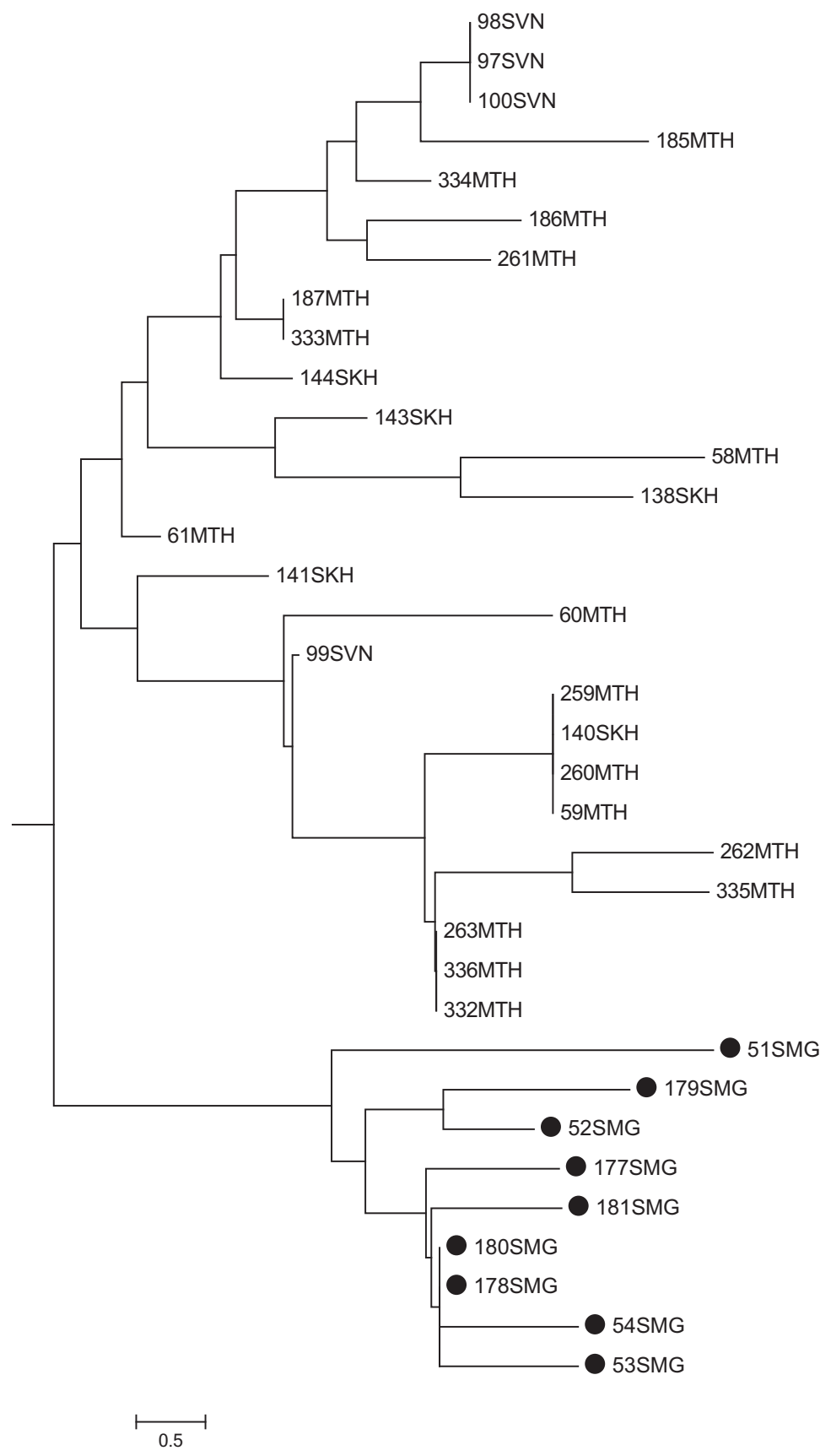

Fig. 2. Genetic variation of D-loop region sequence among the studied individuals of Indian mackerel, Rastrelliger kanagurta, based on the neighbour joining method 
a given population can be defined. The isolated clad of the Indian mackerel population from Madagascar has also proved molecularly identifiable. It provides an opportunity for genetic identification of that population and points to its living in an isolated habitat. It should also be considered whether the genetic distance evaluated by many researchers (Menezes et al. 1993, Darlina et al. 2011) and the assumption about genetic homogeneity of many populations (Ghazali et al. 2012) do not warrant the establishment of catch limits and more extensive protective measures for the whole species. Overfishing of the populations and a low percentage of individuals in the reproductive age result in impoverishment of the genetic pool. It entails lowering of the population variance and its genetic degradation. Further analysis of genetic stability of Indian mackerel populations will enable correct management. Moreover, environmental factors together with high exploitation levels influence will be assessed. Having at our disposal a clearly separated and genetically differentiable population of the Indian mackerel from Madagascar

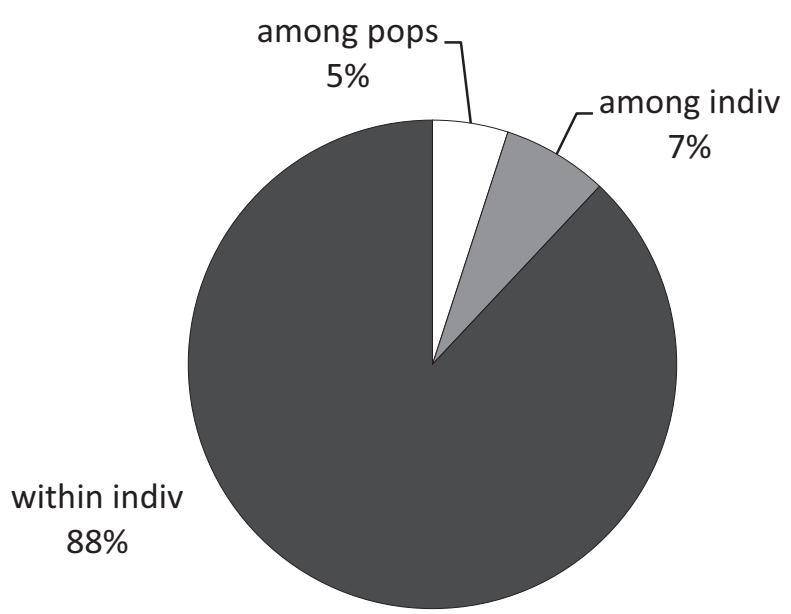

Fig. 3. Percentage of molecular variance (Results of the molecular variance analysis AMOVA) for Madagascar and Cambodia populations of Indian mackerel, Rastrelliger kanagurta; Abbreviations: Among pops $=$ differences among populations, Among Indiv $=$ differences among individuals, Within Indiv $=$ differences within individuals

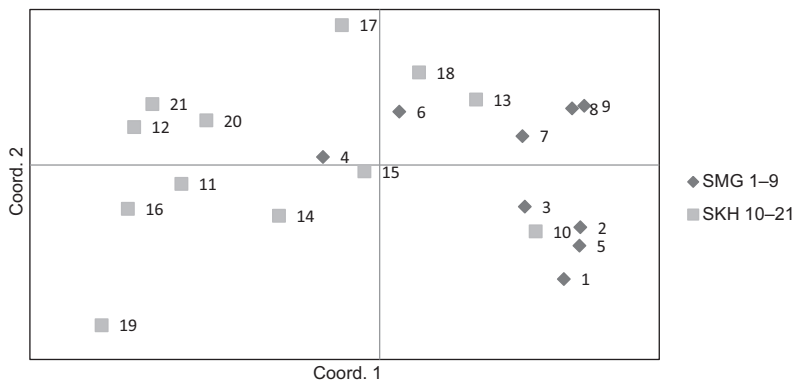

Fig. 4. The principal component analysis (PCA) based on genetic distances between individual fish representing Madagascar (SMG) and Cambodia (SKH) populations of Indian mackerel, Rastrelliger kanagurta we should undertake some measures to protect its genetic pool. As pointed out by Gupta (2010), decreasing biodiversity affects profitability of fishing. It has a special significance in the case of a species exploited as intensely as the Indian mackerel, since the shaking of genetic stability of Cambodian or Thai populations would directly affect the condition of the species which constitutes one of the major sources of inexpensive and accessible protein in many Asian countries. There are no species-specific conservation measures. Better reporting is needed to determine speciesspecific landings if possible. Additionally, given the high combined landings for this species, the unknown level of effort and the absence of an international management body, further monitoring of the Indian mackerel is needed on the national level (Colette et al. 2011).

Our results may help the relevant authorities in the countries of the European Union to identify Indian mackerel and especially its products and trace them to the respective locality. Our findings may also be used for species-specific conservation measures hopefully undertaken by fisheries authorities of the countries where we took our samples. Results on other fish species, prepared in the frames of the same project, will be presented in other papers that will follow soon.

\section{ACKNOWLEDGEMENTS}

The presently reported study is the first part of a larger research project carried out within 2011-2013 and entitled "Development of a genetic-based system for identification of food products form fisheries and aquaculture introduced to the European Union customs area". The project was founded by the European Union (Operational Programme "Sustainable Development of the Fisheries Sector and Coastal Fishing Areas 2007-2013" No. 00002-61720OR1600003/10) and administered by the Agency for Restructuring and Modernisation of Agriculture (ARiMR Poland). The project nicknamed CELFISH was carried out under auspices of- and in a close cooperation with the Customs Chamber in Szczecin (Izba Celna w Szczecinie).

\section{REFERENCES}

Abdussamad E.M., Pillai N.G.K., Kasim H.M., Habeeb Mohamed O.M.M.J., Jeyabalan K. 2010. Fishery, biology and population characteristics of the Indian mackerel, Rastrelliger kanagurta (Cuvier) exploited along the Tuticorin coast. Indian Journal of Fisheries 57 (1): 17-21.

Altschul S.F., Gish W., Miller W., Myers E.W., Lipman D.J. 1990. Basic local alignment search tool. Journal Molecular Biology 215 (3) 403-410. DOI: $10.1016 / \mathrm{S} 0022-$ 2836(05)80360-2

Collette B.B. 2001. Scombridae. Pp. 3721-3756. In: Carpenter K.E., Niem V. (eds.) FAO species identification guide for fishery purposes. The Living Marine Resources of the Western Central Pacific. Vol. 6. Bony fishes part 4 (Labridae to Latimeriidae), estuarine crocodiles, sea turtles, sea snakes and marine mammals. FAO, Rome, Italy.

Collette B., Di Natale A., Fox W., Juan Jorda M., Nelson R. 2011. Rastrelliger kanagurta. In: IUCN Red List of 
Threatened Species. Version 2013.2. Downloaded on 14 May 2014. http://www.iucnredlist.org/details/170328/0

Darlina M.N., Masazurah A.R., Jayasankar P., Jamsari A.F.J., Siti A.M.N. 2011. Morphometric and molecular analysis of mackerel (Rastrelliger spp) from the west coast of Peninsular Malaysia. Genetics and Molecular Research 10 (3): 2078-2092.

Anonymous 2013. Capture production 1950-2011. In: FishStat Plus-Universal software for fishery statistics time series. Version 2.32. FAO, Rome, Italy. Available at: www.fao.org/fishery/statistics/software/fishstat/en

Fisher J. (ed.) 2013. Fish identification tools for biodiversity and fisheries assessments. Review and guidance for decision-makers. FAO Fisheries and Aquaculture Technical Paper 585. FAO, Rome, Italy.

Froese R., Pauly D. (Eds) 2014. FishBase. World Wide Web electronic publication. www.fishbase.org, version (04/2014)

Ghazali A.F., Zailan Abidin D.H., Nor S.A.M., Naim M.D. 2012. Genetic variation of Indian Mackerel (Rastrelliger kanagurta) (Cuvier, 1816) of Sabah waters based on mitochondrial D-loop region: A preliminary study. Asian Journal of Biology and Biotechnology 1 (1): e100 (10 pages).

Gotoh R.O., Tamate S., Yokoyama J., Tamate H.B., Hanzawa N. 2013. Characterization of comparative genome-derived simple sequence repeats for acanthopterygian fishes. Molecular Ecology Resources 13 (3): 461-472. DOI: $10.1111 / 1755-0998.12070$

Gupta A.C. 2010. A dynamic analysis for investigating the linkages between fish biodiversity and profitability. Pp. 235-244. In: Proceedings: International Conference on Applied Economics (ICOAE 2010), 26-28 August 2010, Athens, Greece.

Hall T.A. 1999. BioEdit: a user-friendly biological sequence alignment editor and analysis program for Windows 95/98/NT. Nucleic Acids Symposium Series 41 (1): 95-98.

Hansen M.M., Kenchington E., Nielsen E.E. 2001. Assigning individual fish to populations using microsatellite DNA markers. Fish and Fisheries 2 (2): 93-112. DOI: 10.1046/j.1467-2960.2001.00043.x

Imsiridou A., Apostolidis A.P., Durand J.-D., Briolay J., Bouvet Y., Triantaphyllidis C. 1998. Genetic differentiation and phylogenetic relationship among Greek chub Leuciscus cephalus L. (Pisces Cyprinidae) populations as revealed by RFLP analysis of mitochondrial DNA. Biochemical Systematic and Ecology 26 (4): 415-429. DOI: 10.1016/S0305-1978(97)00123-3

Jayasankar P., Thomas P.C., Paulton M.P., Mathew J. 2004. Morphometric and genetic analyzes of Indian mackerel (Rastrelliger kanagurta) from Peninsular India. Asian Fisheries Science 17 (3): 201-215.

Mehanna S.F. 2001. Dynamics and management of the Indian mackerel Rastrelliger kanagurta (Cuvier, 1816) in the Gulf of Suez, Egypt. Egyptian Journal of Aquatic Biology and Fisheries 5 (3): 179-194.

Menezes M.R., Naik S., Martins M. 1993. Genetic divergence in the Indian mackerel Rastrelliger kanagurta (Cuv) from the coastal waters of Peninsular India and the Andaman Sea. Indian Journal of Fisheries 40 (3): 135-141.

Noble A., Geetha P. 1992. The Indian mackerel Rastrelliger kanagurta (Cuvier) An annotated bibliography. CMFRI Special Publication No. 52, Central Marine Fisheries Institute, Cochin, India.

Peakall R., Smouse P.E. 2012. GenAlEx 6.5: genetic analysis in Excel. Population genetic software for teaching and research-An update. Bioinformatics 28 (19): 2537-2539. DOI: 10.1093/bioinformatics/bts460

Piry S., Alapetite A., Cornuet J.-M., Paetkau D., Baudouin L., Estoup A. 2004. GENECLASS2: A software for genetic assignment and first-generation migrant detection. Journal of Heredity 95 (6): 536-539. DOI: 10.1093/jhered/esh074

Rohit P., Gupta A.C. 2004. Fishery, biology and stock of the Indian mackerel Rastrelliger kanagurta off MangaloreMalpe in Karnataka, India. Journal of the Marine Biological Association of India 46 (2): 185-191.

Sevilla R.G., Diez A., Norén M., Mouchel O., Jérôme M., Verrez-Bagnis V., van Pelt H., Favre-Krey L., Krey G., the Fishtrace Consortium, Bautista J.M. 2007. Primers and polymerase chain reaction conditions for DNA barcoding teleost fish based on the mitochondrial cytochrome $b$ and nuclear rhodopsin genes. Molecular Ecology Notes 7 (5): 730-734. DOI: 10.1111/j.1471-8286.2007.01863.x

Sivadas M., Radhakrishnan Nair P.N., Balasubramanian K.K., Bhaskaran M.M. 2006. Length weight relationship, relative condition, size at first maturity and sex ratio of Indian mackerel Rastrelliger kanagurta from Calicut. Journal of the Marine Biological Association of India 48 (2): 274-277.

Tampubolon G.H., Merta I.G.S. 1987. Mackerel fisheries in the Malacca straits. Pp. 101-116. Investigations on the mackerel and scad resources of the Malacca Straits. Bay of Bengal Programme, Marine Fishery Resources Management BOBP/REP/39 RAS/81/051. FAO, Colombo, Sri Lanka.

Tamura K., Peterson D., Peterson N., Stecher G., Nei M., Kumar S. 2011. MEGA5: molecular evolutionary genetics analysis using maximum likelihood, evolutionary distance, and maximum parsimony methods. Molecular Biology and Evolution 28 (10): 2731-2739. DOI: 10.1093/molbev/msr121

Vincze T., Posfai J., Roberts R.J. 2003. NEBcutter: a program to cleave DNA with restriction enzymes. Nucleic Acids Research 31 (13): 3688-3691. DOI: 10.1093/nar/gkg526

Received: 2 April 2014

Accepted: 18 May 2014

Published electronically: 30 June 2014 